\title{
Relevansi Hak Angket terhadap Komisi Negara Independen
}

\author{
Idul Rishan
}

Faculty of Law, Universities Islam Indonesia

idul.rishan@uii.ac.id

Submitted: 2018-09-29; Reviewed: 2018-10-03; Accepted: 2018-11-22

\begin{abstract}
This study focus into two things. First, the principle of checks and balances of independent state agencys. Second, the relevance of inquiry rights (hak angket) through independent state agencys. This research is normative law research, with historical, conceptual, case and statue approaches. The limitation of study of the independent state agencys are $K Y, K P U$, and $K P K$. The results of study show, (1) there is no independent state agencys that negates the constitutionalism. Each independent state agencys carries out the function of checks and balances. (2) There is no relevance between the right of inquiry and the independent state agencys (KY-KPU-KPK). Historically, conceptually, and normatively, it proves that an independent state commission cannot be the subject of inquiry right
\end{abstract}

Keywords: Independent state agency; inquiry rights; check and balance.

\section{PENDAHULUAN}

Semua berawal dari krisis moneter dan politik pada tahun 1997 dan 1998. Label "reformasi" kemudian melekat sebagai penanda bahwa, Indonesia memasuki suatu fase transisi. Banyak pengamat menyatakan bangsa Indonesia bergerak dari fase otoritarian menuju suatu sistem pemerintahan yang lebih demokratis. ${ }^{1}$ Selain berimbas pada reformasi konstitusi, ${ }^{2}$ fenomena menarik yang dapat dicermati ialah

\footnotetext{
${ }^{1}$ Henk Schulte Nordholt dan Gery van Klinken, Politik Lokal di Indonesia, Jakarta: KITLV-Jakarta \& Yayasan Pustaka Obor Indonesia, 2014, hlm 1.

${ }^{2}$ Setelah melalui masa transisi demokrasi selama periode 1999-2002, stabilitas demokrasi di Indonesia relatif berjalan baik. Empat paket amandemen konstitusi yang rampung pada tahun 2002 menunjukan berakhirnya proses transisi ke arah fase demokrasi. Sejak saat itu, Indonesia telah beranjak menuju konsolidasi demokrasi. Lihat Djayadi Hanan, Menakar Presidensialisme Multipartai di Indonesia; Upaya Mencari Format Demokrasi yang Stabil dan Dinamis Dalam Konteks Indonesia, Bandung:
} 
menjamurnya lembaga-lembaga negara baru yang dikenal dengan istilah komisi negara independen.Fenomena ini dipicu oleh gelombang demokrasi ketiga "the third wave democratization" yang mendorong lahirnya organ-organ negara independen setelah masa transisi politik. ${ }^{3}$

Pelembagaan komisi-komisi negara independen justru mulai mendominasi pada setiap tahapan pembangunan hukum (legal development). Gejala ini hampir mewabah disetiap negara yang melakukan reformasi konstusi,setelah mengalami proses transisi dari otoritarian ke demokrasi. ${ }^{4}$ Hal ini didasarkan atas kompleksitas kebutuhan masyarakat di era modern.Bruce Ackerman justru melihat hadirnya komisi negara independen justru sebagai gejala otokritik terhadap pemisahan kekuasaan secara konvensional antara eksekutif, legislatif, dan yudikatif. Ackerman melihat kecenderungan Amerika yang telah mengadopsi pemisahan kekuasaan berdasar lima cabang yakni Dewan Perwakilan, Senat, Presiden, Mahkamah Agung dan organ independen. ${ }^{5}$

Paham ini kemudian menjadi pembenaran Yves Many dan Andrew Knapp dalam tesisnya the fourth branch of goverment, yang meletakan komisi negara independen sebagai cabang kekuasaan keempat. ${ }^{6}$ Kehadiran komisi negara independen merupakan sebuah inovasi dalam mewujudkan tuntutan kepentingan publik. Kehadiran lembagalembaga negara baru yang dikenal dengan staat auxiliary organ merupakan konsekuensi dari re-distribusi kekuasaan yang dulu bersifat personal kemudian berkembang kearah yang sifatnya impersonal. Artinya, teori separation of power tidak lagi diartikan sebagai pemisahan kekuasaan hanya kepada eksekutif,legislatif, dan yudikatif, melainkan meluas ke lembaga-lembaga independen (independent agencies $)^{7}$

Berkaca dari pengalaman di Amerika Serikat, Susan D. Bear mencatatkan bahwa ketidakpercayaan publik (public distrust) terhadap lembaga negara yang ada telah mendorong lahirnya lembaga negara independen untuk melaksanakan tugas dan diidealkan memberikan kinerja baru yang lebih terpercaya. ${ }^{8}$ Ketidakpercayaan ini tidak

Mizan, 2014, hlm 31.

${ }^{3}$ Samuel P.Huntington, The Third Wave : Democratization in the Late Twentieth Century, Norman: University Oklahoma Press, 1991, p. 209-210.

${ }^{4}$ Said Amir Arjomand, "Law, Political Reconstruction and Constitutional Politics", Journal International Sociology, Volume 18 issue 1, Maret, 2003, p. 9.

${ }^{5}$ Bruce Ackerman, "The New Separation of Power", The Harvard Law Review, Volume 113,HVLR 633, Januari 2000, p. 728.

${ }^{6}$ Lihat Jimly Asshiddiqie, Perkembangan dan Konsolidasi Lembaga Negara Pasca Reformasi, Sinar Grafika, Jakarta, 2010, hlm 8.

${ }^{7}$ Moh.Fajrul Falaakh, "Redistribusi Kekuasaan Negara dan Model Hubungan Antar Lembaga Negara Dalam UUD 1945 Pasca Amandemen" Final Report WCRU-HTN Fakultas Hukum UGM, 2009, Yogyakarta, hlm 20.

${ }^{8}$ Zainal Arifin Mochtar, "Involusi Penataan Lembaga Negara", Makalah \& Bahan Kuliah Magister Ilmu Hukum 2010, Fakultas Hukum Universitas Gadjah Mada, Yogyakarta, 2011, hlm 1. Lihat juga 
hanya dimonopoli oleh publik secara umum, tetapi juga oleh para elit di tingkat atas. Public distrust ini diperkirakan berangkat dari kegagalan lembaga negara akibat meluasnya penyimpangan yang dilakukan dalam kurun waktu yang panjang. ${ }^{9}$

Secara empirik kehadiran komisi negara independen tidak dapat dilepaskan dari kebutuhan percepatan demokrasi. Demokrasi partisipatif dan deliberatif dianggap dapat memberikan ruang yang lebih besar kepada masyarakat untuk ikut berperan mengelola negara melalui lembaga-lembaga khusus. ${ }^{10}$ Eksperimentasi kelembagaan melalui pembentukan organ-organ negara independen dinilai lebih efektif, efisien, powerful, dan tentu saja akomodatif terhadap tuntutan rakyat. ${ }^{11}$

Jika dianalisis secara mendalam, cukup jamak alasan yang melatarbelakangi aras kelahiran komisi-komisi negara independen. Masing-masing riset terdahulu mempunyai titik pijakan dalam melihat fenomena lahirnya komisi-komisi negara independen.Bisa dilihat dari upaya percepatan demokratisasi, bisa dilihat dari ketidakpuasan terhadap kinerja lembaga konvensional yang telah ada, ataupun bisa dilihat dari gejala legal transplant terhadap produk sistem hukum yang telah diterapkan lebih dulu oleh negara lain.

Seperti halnya Komisi Yudisial (KY), Komisi Pemilihan Umum (KPU), dan Komisi Pemberantasan Tindak Pidana Korupsi (KPK), adalah beberapa dari di antara ragam komisi-komisi negara independen yang eksis hingga kini. KY lahir berdasarkan amanat konstitusi Pasal 24B UUD 1945. Organ ini dibentuk guna menjaga independensi peradilan dari intervensi pemerintah dan parlemen, serta meningkatkan fungsi peradilan dengan menggunakan mekanisme pengawasan independen (independent oversight mechanism). ${ }^{12}$

KPU juga dibentuk atas klausul imperatif UUD dalam Pasal 22E ayat 5 yang menyatakan bahwa "pemilihan umum diselenggarakan oleh suatu komisi pemilihan umum yang bersifat tetap, nasional, dan mandiri." Hal ini didasari atas pengalaman penyelenggaraan pemilu pada tahun-tahun sebelumnya yang melahirkan unfair election. Penyebab utama disinyalir akibat penyelenggara pemilu berada di bawah

Susan D. Baer, "The Public Trust Doctrine - A Tool to Make Federal Administrative Agencies Increase Protection of Public Law and Its Resources", Boston, Boston College Environmental Affairs Law Review vol. 15, 1988, p. 382.

${ }^{9}$ Ni'matul Huda, Sengketa Kewenangan Lembaga Negara Dalam Teori dan Praktik di Mahkamah Konstitusi, Yogyakarta: FH UII Press, 2016, hlm 74.

${ }^{10}$ Zainal Arifin Mochtar, Lembaga Negara Independen ; Dinamika, Perkembangan, dan Urgensi Penataannya Kembali Pasca Amandemen Konstitusi, Jakarta: Rajawali Press, 2016, hlm 124.

${ }^{11}$ Gunawan A. Tauda, Komisi Negara Independen; Eksistensi Independent Agencies Sebagai Cabang Kekuasaan Baru Dalam Sistem Ketatanegaraan, Yogyakarta: Genta Press, 2012, hlm 88.

${ }^{12}$ Emilio J Cardenas dan Hector M. Chaver, "Corruption, Accountability and Discipline of Judges in Latin America”, dalam Global Corruption Report Corruption in Judicial System, Transparency Internasional; New York: Cambridge University Press, 2007, p. 45-46. 
intervensi penguasa sehingga sulit untuk berlaku adil. Berkaca dari hal tersebut, penyelenggara pemilu didesain agar bebas dan mandiri. ${ }^{13}$

Kemudian KPK yang di bentuk melalui undang-undang (legislatively based power) sebagai komisi negara independen. Politik hukum pelembagaan KPK dimulai dalam satu tarikan nafas dengan upaya memberantas korupsi, kolusi, dan nepotisme. ${ }^{14}$ Kehadiran KPK merupakan wajah baru dalam pemberantasan korupsi, yang hadir sebagai gejala reaksional atas kurang optimalnya kinerja kepolisian dan kejaksaan.

Harus diakui setelah delapan belas tahun usia reformasi bergulir, kelahiran komisi negara independen berkembang cukup pesat. Ide demi ide pelembagaan komisi negara independen lahir berdasar gejala reaksional, reaktif, sektoral, dan sangat dadakan, tetapi dibungkus oleh idealisme dan heroisme yang tinggi. Hal tersebut juga didukung oleh momentum politik yang membuka ruang demokratisasi di segala bidang. Oleh karena itu tren pembentukan lembaga-lembaga baru tumbuh bagaikan cendawan di musim hujan. Jumlahnya banyak sekali, namun tidak disertai dengan desain yang matang dan komperhensif. ${ }^{15}$

Ketiadaan grand design terhadap komisi negara independen memunculkan dua garis besar isu aktual yang belum terjawab oleh riset-riset sebelumnya. Pertama, di tahun 2006 Mahkamah Konstitusi (MK) menyatakan pandangnnya terhadap komisi negara independen dalam Putusan Nomor 005/PUU-IV/2006, yang menurut hemat penuliscukup problematik. MK mendalihkan bahwa "....memahami hubungan antara lembaga negara dalam perspektif "checks and balances" di luar konteks pemisahan fungsi-fungsi kekuasaan negara (separation of powers), seperti dalam hubungan antara Mahkamah Agung dan Komisi Yudisial, adalah tidak tepat..." ${ }^{16} \mathrm{MK}$ mencoba membangun argumen dengan menyatakan oleh karena KY staat auxiliary maka KY tidak dapat melaksanakan fungsi checks and balances terhadap lembaga-lembaga utama (main organ). ${ }^{17}$

Dalam tataran praktis hal ini menjadi sebuah pertanyaan besar, sebab KY yang melaksanakan fungsi pengawasan, namun di awasi oleh siapa? Perdebatan ini mengingatkan kembali pada tesis lama Mauro Cappeletii tentang who watches the watchmen $?^{18}$ Apakah benar komisi negara independen tidak dapat melaksanakan

\footnotetext{
${ }^{13}$ Ni'matul Huda dan M. Imam Nasef, Penataan Demokrasi \& Pemilu di Indonesia Pasca Reformasi, Kencana, Jakarta, 2017, hlm 56.

14 Denny Indrayana, Jangan Bunuh KPK; Kajian Hukum Tata Negara Penguatan Komisi Pemberantasan Korupsi, Malang: Intrans Publishing, 2016, hlm 34.

15 Jimly Asshidiqie, Penguatan Sistem Pemerintahan dan Peradilan, Jakarta: Sinar Grafika, 2015, hlm 92.

${ }^{16}$ Lihat Putusan MK Nomor 005/PUU-IV/2006, hlm 179.

${ }^{17}$ Ibid., hlm 180

${ }^{18}$ Mauro Cappeleti, "Who watches the watchmen?"A comparative Study on Judicial Responsibility, The American Journal of Comparative Law, Volume 31, No. 1, 1983, p. 1.
} 
fungsi checks and balances? Hal ini perlu dijawab dan disertai dengan analisis yang tajam dalam sebuah riset.

Kedua, fakta empiris di atas cukup berbanding terbalik dengan apa yang dialami oleh KPK. Di anggap sebagai lembaga negara yang superbody dan minim pengawasan, membuat Dewan Perwakilan Rakyat (DPR) melakukan upaya pengawasan melalui hak angket ${ }^{19}$ sebagai bentuk checks and balances ${ }^{20}$ terhadap komisi anti rasuah tersebut. Langkah DPR melaksanakan hak angket terhadap kinerja KPK merupakan persitiwa politik yang cukup menyita banyak perhatian. Termasuk kalangan akademisi yang suara intelektualnya terdikotomis secara vis a vis. Sebagian menyatakan bahwa tindakan DPR konstitusional, namun di lain pihak menyatakan bahwa langkah DPR merupakan tindakan yang inkonstitusional.

Masing-masing peristiwa tersebut memunculkan hipotesa, apakah benar saat ini komisi-komisi negara independen menjadi salah satu poros kekuasaan yang tidak terkontrol? Apakah relevan hak angket DPR ditujukan kepada komisi negara independen? Berangkat dari dua titik pijakan tersebut, studi ini merupakan kajian yang perlu direspon dalam ruang lingkup akademik. Kemudian dipandang layak untuk melakukan penelitian lebih lanjut, dan menuangkannya ke dalam sebuah riset.

\section{Rumusan Masalah}

Berdasarkan latar belakang permasalahan yang dirumuskan oleh penulis, riset ini menawarkan dua rumusan masalah. Pertama, bagaimana prinsip checks and balances terhadap komisi negara independen? Kedua, bagaimana relevansi hak angket terhadap komisi negara independen?

19 Berdasarkan Pasal 79 ayat (3) Undang-Undang Nomor 17 Tahun 2014 Tentang Majelis Permusyawaratan Rakyat, Dewan Perwakilan Rakyat, Dewan Perwakilan Daerah, Dewan Perwakilan Rakyat Daerah, menyatakan bahwa "Hak angket sebagaimana dimaksud pada ayat (1) huruf b adalah hak DPR untuk melakukan penyelidikan terhadap pelaksanaan suatu undang-undang dan/atau kebijakan Pemerintah yang berkaitan dengan hal penting, strategis, dan berdampak luas pada kehidupan bermasyarakat, berbangsa, dan bernegara yang diduga bertentangan dengan peraturan perundang-undangan"

${ }^{20}$ Secara terminologis checks and balances berdasarkan Black's Law Dictionary, diartikan sebagai "arrangement of governmental powers whereby powers of one governmental branch check or balance those of other brances. Berdasarkan pengertian ini dapat disimpulkan bahwa checks and balances merupakan suatu prinsip yang saling mengimbangi dan mengawasi antar cabang kekuasaan satu dengan yang lainnya. Tujuannya untuk menghindari adanya kosentrasi kekuasaan pada satu cabang kekuasaan tertentu. Lihat Henry Campbell Black, 1991, Black Dictionary, St.Paul, Minnesota: West Publishing, hlm 238. Bandingkan dengan Munir Fuady yang menyatakan bahwa, kata checks merupakan suatu pengontrolan yang satu dengan yang lain, agar suatu pemegang kekuasaan tidak berbuat sebebasbebasnya yang dapat menimbulkan kesewenang-wenangan. Sedangkan balances merupakan suatu keseimbangan kekuasaan agar masing-masing pemegang kekuasaan tidak cenderung terlalu kuat sehingga menimbulkan tirani. Pada prinsipnya konsep checks and balances ini lahir akibat adanya distribusi kekuasaan antar alat kelengkapan organ negara yang diharapkan satu sama lain saling mengimbangi. Lihat juga, Munir Fuady, 2009, Teori Negara Hukum Modern, Bandung: Refika Aditama, Bandung, hlm. 124 


\section{Metode Penelitian}

Penelitian ini merupakan penelitian yuridis normatif. ${ }^{21}$ Pendekatan yang dipakai antara lain historical approach, statue approach, dan conceptual approach ${ }^{22}$ Objek penelitian terhadap komisi negara independen dilakukan terhadap KY, KPU, dan KPK. Data yang dipakai adalah data sekunder. Bahan yang digunakan dalam penelitian ini adalah bahan primer, sekunder dan tersier. ${ }^{23}$ Pemilihan terhadap tiga komisi negara independen tersebut dipilih penulis berdasarkan dua alasan yakni, pertama, sifat constitutional importance yang dimiliki oleh masing-masing lembaga negara tersebut. Kedua, akibat besarnya resistensi kelembagaan terhadap tiga komisi negara independen tersebut, dengan organ-organ utama konstitusi.

\section{PEMBAHASAN}

\section{Prinsip Checks \& Balances KNI}

Berdasarkan hasil penelitian, prinsip checks and balances terhadap komisi negara independen dapat diidentifikasi melalui tiga fase. Fase pertama dapat dilihat dari model pengangkatan komisioner, fase kedua dapat diidentifikasi melalui hubungan kewenangan dengan cabang kekuasaan lainnya, fase ketiga, dapat diidentifikasi melalui akuntabilitas hubungan antar kelembagaan.Berikut pemetaan terhadap masing-masing komisi negara independen yang menjadi objek studi terhadap penelitian ini.

\section{Komisi Yudisial}

Jika dianalisis secara mendalam, prinsip chekcs and balances terhadap KY telah diatur secara detail mulai dari proses hulu sampai dengan hilirnya. Proses hulunya meliputi mekanisme pengangkatan komisioner, sedangkan proses hilirnya dapat dilihat dari pola hubungan kewenangan dan akuntabilitas hubungan kelembagaannya. Dalam hal pengangkatan komisioner KY, UUD mendelegasikan kepada pembentuk undang-undang sebagai open legal policy. ${ }^{24}$ Melalui Pasal 28 UU Nomor 18 Tahun 2011, mekanisme pengangkatan komisioner KY diusulkan oleh Panitia Seleksi (Pansel) yang dibentuk oleh pemerintah berdasarkan keterwakilan golongan. Ponsel terdiri dari unsur pemerintah, praktisi hukum, akademisi hukum, dan anggota masyarakat.Konsep keterwakilan golongan dalam komposisi pansel, dibentuk dengan tujuan agar Pansel dapat bekerja secara independen dan akuntabel. Meskipun secara hierarkis dibentuk berdasarkan

\footnotetext{
${ }^{21}$ F. Sugeng Istanto, Penelitian Hukum, Yogyakarta: Ganda, 2007, hlm. 29.

${ }^{22}$ Peter Mahmud Marzuki, Penelitian Hukum, Kencana Prenada, Jakarta: Media Group, 2005 hlm 29.

${ }^{23}$ Soerjono Soekanto, Pengantar Penelitian Hukum, Jakarta: UI Press, 1986, hlm 51.

${ }^{24}$ Susunan, keududukan, dan keanggotaan Komisi Yudisial diatur dengan undang-undang. Lihat Pasal 24B ayat (4) UUD 1945 Setelah Perubahan.
} 
Keputusan Presiden, namun secara fungsional tidak berada di bawah pengaruh Presiden, atau tidak menjadi subordinasi dari political demand atau political will Presiden.

Pansel melakukan penjaringan sebanyak 21 nama calon kemudian diajukan ke Dewan Perwakilan Rakyat (DPR) untuk ditetapkan tujuh nama calon yang masingmasing terdiri dari 2 (dua) orang mantan hakim, 2 (dua) orang praktisi hukum,2 (dua) orang akademisi hukum, dan 1 (satu) orang anggota masyarakat. ${ }^{25}$ Setelah ditetapkan tujuh nama calon komisioner KY, DPR menyerahkan kepada Presiden untuk dilantik dan ditetapkan sebagai komisioner terpilih. Jika dilihat dari mekanisme pengangkatan komisioner, metode seleksi berjenjang dengan melibatkan peran Pansel, DPR, dan Presiden, memberi penegasan bahwa prinsip chekcs and balances telah melekat pada mekanisme pengangkatan komisioner KY.

Jika dianalisis dari hubungan kewenangan, terdapat dua kewenangan KY yang secara konstitusional diberikan oleh UUD. Pertama, mengusulkan pengangkatan calon hakim agung.Pasal 24A ayat (3) UUD 1945, telah menyatakan bahwa dalam hal pengangkatan calon hakim agung, terdapat tiga poros kekuasaan yang terlibat secara langsung (KY-DPR-Presiden) dalam proses pengangkatan hakim agung. Penjaringan dilakukan oleh KY kemudian dimintakan persetujuan oleh DPR (right to confirm) dan diserahkan kepada Presiden untuk ditetapkan sebagai hakim agung. Di satu sisi, keterlibatan KY sebagai komisi negara independen diperlukan untuk meminimalisir masuknya kepentingan politik dalam penjaringan calon hakim agung. Di sisi lain, keterlibatan DPR dan Presiden juga diperlukan sebagai bentuk akuntabilitas terhadap kinerja KY dalam menjaring calon hakim agung.Artinya secara konseptual keterlibatan masing-masing lembaga dapat dimaknai sebagai bentuk chekcs and balances terhadap proses pengangkatan hakim agung.

Kedua, menjaga dan menegakkan kehormatan, keluhuran martabat, serta perilaku hakim. Pada titik ini, diperlukan kehati-hatian dalam memahami hubungan pengawasan antara KY dan perilaku hakim. Bahwa benar jika dikatakan subjek pengawasan KY diletakkan pada etika dan kehormatan perilaku hakim, dan bukan pada fungsi kelembagaan MA atau badan peradilan. Sebab, KY tidak mengawasi produk putusan yang dikeluarkan oleh badan peradilan.

Namun, tidak tepat jika lahir konklusi yang menyatakan KY tidak melaksanakan fungsi checks and balances dalam konteks pengawasan etika dan perilaku hakim. Seperti contohnya, mekanisme pemeriksaan bersama dan

${ }^{25}$ Lihat Pasal 6 ayat (3) Undang-Undang Nomor 18 Tahun 2011 Tentang Perubahan Atas UndangUndang Nomor 22 Tahun 2004 Tentang Komisi Yudisial. 
ataupenolakan/veto MA terhadap usulan penjatuhan sanksi yang dilakukan oleh KY. Dalam hal ini veto tidak dilakukan oleh individu hakim melainkan oleh kelembagaan MA itu sendiri. ${ }^{26}$ Lahirnya model pengusulan (proposed) dan penolakan (veto) antara KY dan MA, secara konseptual telah melahirkan prinsip checks and balancesantara masing-masing lembaga tersebut.

Terakhir jika dianalisis dari aspekakuntabilitas hubungan kelembagaan, KY bertanggung jawab kepada publik melalui representasi perwakilan di DPR baik dalam aspek kinerja maupun penggunaan anggaran yang sebelumnya diaudit lebih dulu melalui Badan Pemeriksa Keuangan (BPK). ${ }^{27}$ Artinya, jika dilihat berdasarkan tiga fase pengelompokan terhadap prinsip checks and balances, KY memenuhi masing-masing fase tersebut.

\section{Komisi Pemilihan Umum}

Berdasarkan tipologi kelembagaan, komisi pemilihan umum (KPU) masuk dalam kategori lembaga negara independen yang namanya disebut dalam UUD tanpa menggunakan huruf kapital, disebut fungsinya, namun kewenangannya diatur lebih lanjut dengan undang-undang.Secara teoritik, KPU melakasanakan fungsi campur sari. Karakteristik ini dapat dilihat dari fungsinya yang melaksanakan quasi eksekutif dan semi regulatif. Saat ini, perihal kedudukan dan kewenangan KPU diatur dengan Undang-Undang Nomor 15 Tahun 2011 Tentang Penyelenggara Pemilihan Umum.

Undang-Undang Penyelenggara Pemilu memberikan pengaturan secara eksplisit terkait mekanisme pengangkatan komisioner KPU. ${ }^{28}$ Lazimnya pengangkatan komisoner komisi-komisi negara independen, pembentukan Pansel oleh Presiden menjadi salah satu alternatif untuk menjaring bakal calon yang dinilai memiliki integritas dan kapabilitas. Pansel dibentuk dengan menjaga komposisi keterwakilan golongan, khusunya perempuan. ${ }^{29}$ Pansel bekerja secara transparan dan independen dengan melibatkan partisipasi masyarakat. ${ }^{30}$ Setelah

\footnotetext{
${ }^{26}$ Sangat dimungkinkan terjadi penolakan MA terhadap usulan penjatuhan sanksi yang dilakukan KY terhadap seorang hakim. Veto bisa dilakukan MA sepanjang materi pelanggaran masuk dalam ranah wilayah teknis yudisial atau menyangkut aspek Putusan hakim. Hal ini diatur secara implisit, kemudian penulis menafsirkan secara a contrario Lihat Pasal 22E, 22F, dan 22B Undang-Undang Nomor 18 Tahun 2011 Tentang Perubahan Atas Undang-Undang Nomor 22 Tahun 2004 Tentang Komisi Yudisial.

${ }^{27}$ Lihat Pasal 38 Undang-Undang Nomor 18 Tahun 2011 Tentang Perubahan Atas Undang-Undang Nomor 22 Tahun 2004 Tentang Komisi Yudisial.

${ }^{28}$ Dalam hal ini, penulis membatasi kajian riset hanya pada KPU, dan tidak pada KPU Provinsi dan Kabupaten Kota.

${ }^{29}$ Lihat Pasal 12 ayat (1) Undang-Undang Nomor 15 Tahun 2011 Tentang Penyelenggara Pemilihan Umum.

${ }^{30}$ Lihat Pasal 13 ayat (1) Undang-Undang Nomor 15 Tahun 2011 Tentang Penyelenggara Pemilihan Umum.
} 
melakukan penjaringan, Pansel mengajukan 14 nama calon kepada DPR untuk dipilih tujuh nama,kemudian ditetapkan oleh Presiden sebagai komisioner terpilih. ${ }^{31}$

Jika dilihat dari hubungan kewenangan, ${ }^{32}$ KPU menjadi salah satu komisi negara independen yang mempunyai ragam alternatif pembatasan kekuasaan. Pertama, secara kelembagaan, KPU diawasi oleh Badan Pengawas Pemilu (Bawaslu) dalam setiap tingkatan fungsinya. Kedua, dilihat dari aspek etika penyelenggara pemilu, anggota KPU yang melanggar kode etik, dapat dimintakan proses ajudikasi melalui Dewan Kehormatan Penyelenggara Pemilu (DKPP).

Ketiga, selain masing-masing pembatasan kekuasaan di atas, berdasarkan Surat Edaran Mahkamah Agung (SEMA) Nomor 7 Tahun 2010 Tentang Petunjuk Teknis Sengketa Mengenai Pemilihan Umum Kepala Daerah, ${ }^{33}$ lembaga peradilan juga mempunyai fungsi korektif terhadap keputusan-keputusan yang ditetapkan KPU melalui Peradilan Tata Usaha Negara (PTUN). Pada prinsipnya SEMA memberikan ruang bagi para pencari keadilan, untuk menguji keputusankeputusan KPU, sepanjang berkaitan dengan persiapan penyelenggaraan pemilu. Seperti contohnya tahap pendaftaran pemilih, tahap pencalonan peserta dan atau tahap masa kampanye.Terkait dengan hasil pemilu, jalur pembatasan kekuasaan KPU diserahkan kepada Mahkamah Konstitusi (MK), untuk menguji konstitusionalitas hasil penyelenggaraan pemilu. ${ }^{34}$

Lebih dari itu, sebagai komisi negara independen yang mempunyai kewenangan self regulatory agencies (kewenangan menetapkan peraturan internal), KPU tetap mempunyai fungsi koordinasi dengan DPR. Apabila terjadi penyalahgunaan kekuasaan oleh KPU dalam menetapkan peraturan internal, Mahkamah Agung (MA) mempunyai fungsi korektif dalam menguji konstitusionalitas peraturan KPU di bawah undang-undang. ${ }^{35}$ Konstelasi hubungan kewenangan yang saling korektif baik sesama penyelenggara pemilu, cabang

\footnotetext{
${ }^{31}$ Lihat Pasal 15dan 16Undang-Undang Nomor 15 Tahun 2011 Tentang Penyelenggara Pemilihan Umum.

${ }^{32}$ Lihat kewenangan KPU pada Pasal 8 Undang-Undang Nomor 15 Tahun 2011 Tentang Penyelenggara Pemilihan Umum.

${ }^{33}$ Dalam perspektif politik hukum, SEMA ini lahir untuk menjawab perdebatan akademis yang lahir melalui Pasal 2 huruf g UU No 5 Tahun 1986 tentang Peradilan Tata Usaha Negara yang telah diubah dengan UU No. 51 Tahun 2009 (UU PTUN), secara implisit menyebutkan "Keputusan KPU baik di tingkat pusat maupun daerah mengenai hasil pemilihan umum, tidak menjadi objek sengketa di PTUN". Adanya SEMA ini, memberikan eskalasi terhadap kompetensi PTUN untuk mengoreksi keputusankeputusan yang ditetapkan KPU, sepanjang terkait proses persiapan penyelenggaraan pemilu, bukan terhadap hasil pemilu.

${ }^{34}$ Lihat Pasal 24C ayat (1) UUD 1945.

${ }^{35}$ Peraturan KPU masuk dalam hierarki peraturan perundang-undangan di bawah UU, lihat Pasal 8 ayat (1) UU Nomor 12 Tahun 2011 Tentang Pembentukan Peraturan Perundang-undangan.
} 
legislatif (DPR), dan yudikatif (MA), memberi penegasan bahwa KPU melaksanakan fungsi chekcs and balances.

Jika dilihat dari akuntabilitas hubungan kelembagaan,KPU bertanggung jawab kepada rakyat melalui DPRdalam bentuk laporan berkala. Untuk penggunaan anggaran, KPU bertanggung jawab sesuai dengan peraturan perundangundangan. ${ }^{36}$ Melihat masing-masing fase di atas mulai dari pengangkatan komisioner, hubungan kewenangan, dan akuntabilitas kelembagaan, KPU menjadi komisi negara independen yang melaksanakan fungsi checks and balances.

\section{Komisi Pemberantasan Korupsi (KPK)}

KPK merupakan komisi negara independen yang kedudukannya sebagai bagian yang mendukung fungsi kekuasaan kehakiman. Penafsiran ini dinyatakan melalui Putusan MK yang menyatakan bahwa,KPK merupakan organ penting konstitusi (constitutionally important) dan termasuk lembaga yang fungsinya berkaitan dengan kekuasaan kehakiman sebagaimana dimaksud oleh Pasal 24 Ayat (3) UUD 1945 ". ${ }^{37}$

Selain Komisi Yudisial (KY), Komisi Pemberantasan Korupsi (KPK) tercatat sebagai komisi negara independen yang sepak terjangnya kerap menuai resistensi dengan lembaga negara lainnya. Resistensi itu kerap lahir melalui DPR, Kepolisian, maupun oleh Badan Pemeriksa Keuangan. Peristiwa hak angket KPK dapat dikategorikan sebagai peristiwa paling anyar setelah pelembagaannya tahun 2002.

Kedudukan, fungsi, dan kewenangan KPK diberikan melalui pembentuk undang-undang (legislatively based power) melalui Undang-Undang Nomor 30 Tahun 2002 Tentang Komisi Pemberantasan Tindak Pidana Korupsi. Konsideran lahirnya undang-undang ini tidak bisa dilepaskan dari peran lembaga pemerintah (Kepolisian dan Kejaksaan) dalam menangani pencegahan dan pemberantasan korupsi yang dianggap belum optimal. ${ }^{38}$

Sama halnya dengan KY dan KPU, mekanisme penjaringan calonkomisioner KPK, dilakukan oleh Pansel yang dibentuk oleh Presiden. Alternatif penjaringan melalui Pansel dipilih agar menjaga independensi kelembagaan komisi negara independen. Berdasarkan UU KPK, Pansel dibentuk atas keterwakilan golongan yang meliputi unsur pemerintah dan tokoh masyarakat. ${ }^{39}$ Pansel dituntut bekerja secara transparan, akuntabel, dan partisipatifdalam menjaring bakal calon

\footnotetext{
${ }^{36}$ Pasal 37 Undang-Undang Nomor 15 Tahun 2011 Tentang Penyelenggara Pemilihan Umum.

${ }^{37}$ Lihat Pertimbangan Putusan MK Nomor 012-016-019/PUU-IV/2006.

${ }^{38}$ Lihat konsideran huruf b Undang-Undang Nomor 30 Tahun 2002 Tentang Komisi Pemberantasan Tindak Pidana Korupsi.

39 Lihat Pasal 30 ayat (1) dan (3) Undang-Undang Nomor 30 Tahun 2002 Tentang Komisi Pemberantasan Tindak Pidana Korupsi.
} 
komisioner KPK. Setelah melakukan penjaringan, Pansel menetapkan calon komisioner untuk diserahkan dan dipilih oleh DPR. Mekanisme pengangkatan calon komisioner KPK kepada DPR dilakukan dengan model berbasis rasio 1:2. Artinya berlaku kelipatan sesuai dengan jumlah formasi jabatan yang dibutuhkan. Seperti contohnya 4 untuk 2 formasi, 6 untuk 3 formasi dan seterusnya berlaku berdasarkan kelipatan. ${ }^{40}$

Setelah nama calon diserahkan kepada DPR, calon komisioner patut melewati tahapan seleksi yang dilakukan oleh komisi III DPR untuk dipilih dan ditetapkan sebagai calon komisioner KPK.Pada prinsipnya DPR akan menetapkan calon komisioner berdasarkan jumlah formasi yang dibutuhkan, kemudian diserahkan kepada Presiden.Secara seremonial, calon ketua dan anggota ditetapkan kemudian oleh Presiden sebagai komisioner terpilih. Dari ketiga komisi negara yang diteliti (KY-KPU-KPK), secara umum menggunakan konsep yang sama dalam mekanisme pengangkatan komisioner. Sebagaimana dilakukan oleh Pansel kemudian diserahkan kepada DPR dan ditetapkan oleh Presiden.

Dilihat dari hubungan kewenangan, pembatasan kekuasaan KPK dilakukan secara tunggal melalui lembaga peradilan (kekuasaan kehakiman). Tipologi pembatasan kekuasaan KPK melalui lembaga peradilan dibagi atas praperadilan, peradilan, dan upaya hukum biasa/luar biasa.Praperadilan menjadi instrumen kontrol lapispertama untuk mengimbangi kewenangan KPK. Secara normatif Kitab Undang-Undang Hukum Acara Pidana (KUHAP) mengatur secara eksplisit objek yang dimohonkan melalui praperadilan. Pasal 77 KUHAP menyatakan:

"Pengadilan negeri berwenang untuk memeriksa dan memutus, sesuai dengan ketentuan yang diatur dalam undang-undang ini tentang: (a) sah atau tidaknya penangkapan, penahanan, penghentian penyidikan atau penghentian penuntutan; (b) ganti kerugian dan atau rehabilitasi bagi seorang yang perkara pidananya dihentikan pada tingkat penyidikan atau penuntutan."

Pada tahun 2014, frasa di atas dimintakan uji materil ke Mahkamah Konstitusi sebagaimana dimohonkan oleh terpidana kasus korupsi bioremediasi fiktif PT. Chevron Pasific Indonesia Bachtiar Abdul Fatah. Fatah memberikan kuasanya kepada Maqdir Ismail yang pada hakekatnya meminta MK memberikan penafsiran secara bersyarat (conditionally unconstitutional) terhadap Pasal 77 ayat (1) KUHAP, dengan memperluas kompetensipraperadilan.Melalui Putusan MK Nomor 21/PUU-XII/2014, majelis hakim dalam putusannya menyatakan Pasal 77

${ }^{40}$ Lihat Pasal 30 ayat (9) Undang-Undang Nomor 30 Tahun 2002 Tentang Komisi Pemberantasan Tindak Pidana Korupsi. 
ayat (1) KUHAP bertentangan dengan UUD sepanjang tidak dimaknai status penetapan tersangka sebagai objek praperadilan. ${ }^{41}$

\section{Dalam pertimbangannya MK menyatakan;}

“...KUHAP tidak memiliki checks and balance system atas tindakan penetapan tersangka oleh penyidik karena KUHAP tidak mengenal mekanisme pengujian atas keabsahan perolehan alat bukti dan tidak menerapkan prinsip pengecualian (exclusionary) atas alat bukti yang diperoleh secara tidak sah seperti di Amerika Serikat. Contoh mekanisme pengujian terhadap keabsahan perolehan alat bukti dapat dilihat dalam kasus Dominique Straus Kahn yang dituduh melakukan perkosaan terhadap Nafissatou Diallo di Hotel Manhattan New York pada tahun $2011 \ldots .42$

Lebih lanjut MK menyatakan;

“...bahwa pada saat KUHAP diberlakukan pada tahun 1981, penetapan tersangka belum menjadi isu krusial dan problematik dalam kehidupan masyarakat Indonesia. Upaya paksa pada masa itu secara konvensional dimaknai sebatas pada penangkapan, penahanan, penyidikan, dan penuntutan, namun pada masa sekarang bentuk upaya paksa telah mengalami berbagai perkembangan atau modifikasi yang salah satu bentuknya adalah "penetapan tersangka oleh penyidik" yang dilakukan oleh negara dalam bentuk pemberian label atau status tersangka pada seseorang

\footnotetext{
${ }^{41}$ Lihat Putusan MK Nomor 21/PUU-XII/2014

${ }^{42}$ Kasus tersebut akhirnya dibatalkan pada Agustus 2011 di Magistrates Court New York, setelah adanya keraguan terhadap kredibilitas saksi korban, termasuk kesaksiannya yang tidak konsisten tentang apa yang terjadi. Hal yang melatarbelakangi alat bukti harus diuji keabsahan perolehannya. Menurut Paul Roberts dan Adrian Zuckerman, ada tiga prinsip yang mendasari perlunya mekanisme pengujian atas keabsahan perolehan alat bukti, yaitu: Pertama, rights protection by the state. Hak tersebut lahir karena terkadang upaya dari penyelidik atau penyidik dalam menemukan alat bukti dilakukan dengan melanggar hak asasi calon tersangka atau tersangka. Dalam rangka mengembalikan atau mempertahankan hak yang sudah dilanggar maka diperlukan suatu mekanisme pengujian perolehan alat bukti untuk mengetahui dan memastikan apakah alat bukti tersebut sudah benar-benar diambil secara sah. Kedua, deterrence (disciplining the police). Pengesampingan atau pengecualian alat bukti yang diambil atau diperoleh secara tidak sah, akan mencegah/menghalangi para penyidik maupun penuntut umum mengulangi kembali kesalahan mereka di masa mendatang. Apabila hakim secara rutin mengecualikan/mengesampingkan alat bukti yang didapat secara tidak sah tersebut, maka hal itu menjadi pesan yang sangat jelas kepada aparat penegak hukum bahwa tidak ada manfaat yang bisa diambil dari melanggar hukum, kemudian motivasi dari aparat untuk melanggar hukum akan menurun drastis. Ketiga, the legitimacy of the verdict. Dalam proses acara pidana diperlukan suatu sistem yang dapat dipercaya sehingga masyarakat yakin terhadap sistem hukum atau sistem peradilannya. Apabila hakim sudah terbiasa memaklumi aparat penyidik dan penuntut umum dalam menyajikan alat bukti yang didapat secara tidak sah, maka sistem hukum tersebut akan diragukan legitimasinya dan masyarakat akan segera mengurangi rasa hormatnya. [Paul Roberts and Adrian Zuckerman, Criminal Evidence. (New York: Oxford University Press Inc, reprinted 2008), hal. 149-159]. Dikutip dalam pertimbangan Putusan MK Nomor 21/PUU-XII/2014, hlm 103.
} 
tanpa adanya batas waktu yang jelas, sehingga seseorang tersebut dipaksa oleh negara untuk menerima status tersangka tanpa tersedianya kesempatan baginya untuk melakukan upaya hukum untuk menguji legalitas dan kemurnian tujuan dari penetapan tersangka tersebut. Padahal hukum harus mengadopsi tujuan keadilan dan kemanfaatan secara bersamaan sehingga jika kehidupan sosial semakin kompleks maka hukum perlu lebih dikonkretkan secara ilmiah dengan menggunakan bahasa yang lebih baik dan sempurna (Shidarta, 2013: 207-214). Dengan kata lain, prinsip kehati-hatian haruslah dipegang teguh oleh penegak hukum dalam menetapkan seseorang menjadi tersangka..." 43

Implikasi Putusan MK Nomor 21/PUU-XII/2014, membuka ruang pengawasan yang lebih lebar terhadap kinerja KPK dalam penetapan status tersangka. Budi Gunawan, Hadi Poernomo, dan Setya Novanto ialah beberapa contoh praperadilan yang dikabulkan permohonannya akibat tidak sahnya penetapan status tersangka.

Kontrol lapis kedua dilakukan dengan skema proses peradilan pada pengadilan tingkat pertama dan tingkat banding (judex facti). Terakhir ialah kontrol lapis ketiga yang dilakukan melalui skema upaya hukum kasasi (judex juris) di Mahkamah Agung. Judex facti dilakukan untuk memeriksa fakta dan bukti dari suatu perkara, sedangkan judex juris dilakukan untuk memeriksa penerapan hukum dari suatu perkara. ${ }^{44}$ Artinya jika dilihat dari hubungan kewenangan, perimbangan kekuasaan KPK hanya terletak pada poros lembaga kehakiman. Hal ini didasarkan agar proses penegakan hukum dilakukan secara independen dan imparsial.

Dilihat dari aspek akuntabilitas hubungan kelembagaan, KPK bertanggung jawab kepada publik atas pelaksanaan tugasnya dan menyampaikan laporannya secara terbuka dan berkala kepada Presiden, DPR, dan Badan Pemeriksa Keuangan (BPK), baik itu berupa laporan tahunan, penggunaan anggaran dan akses informasi publik. ${ }^{45}$ Masing-masing fase di atas, mulai dari pengangkatan komisioner, hubungan kewenangan, dan akuntabilitas kelembagaan, KPK menjadi komisi negara independen yang melaksanakan fungsi checks and balances.

\section{Relevansi Hak Angket Terhadap KNI}

Pada tahap ini, untuk melihat lebih jauh apakah hak angket DPR dapat ditujukan kepada komisi negara independen (KY-KPU-KPK), diperlukan tiga pendekatan untuk

\footnotetext{
${ }^{43}$ Ibid, hlm 104.

${ }^{44}$ Lihat Dudu Duswara Machmudin, "Optimalisasi Peran Hakim Agung Dalam Penyelesaian Perkara Kasasi dan Peninjauan Kembali”, Jurnal Konstitusi Volume 12 Nomor 2, Juni 2015, hlm. 379-380.

45 Lihat Pasal 20 ayat (1) dan (2) Undang-Undang Nomor 30 Tahun 2002 Tentang Komisi Pemberantasan Tindak Pidana Korupsi.
} 
menjawab persoalan tersebut. Masing-masing pendekatan tersebut ialah konteks historis, konseptual (theoritical framework), dan normatif. Secara historis, pengaturan tentang hak angket dan interpelasi DPR pertama kali muncul pada Pasal 120 dan 121 Konstitusi Republik Indonesia Serikat (RIS). Kemudian masuk pada fase tahun 1950 klausul tersebut kembali diadopsi pada Undang-Undang Nomor 7 Tahun 1950 Tentang Perubahan Konstitusi Sementara Menjadi Undang-Undang Dasar Sementara Republik Indonesia. Lebih lanjut penulis menggunakan istilah Undang-Undang Dasar Sementara Tahun 1950 (UUDS 1950). Pasal 69 dan 70 memberikan hak secara konstitusional kepada DPR untuk memberikan pertanyaan kepada pemerintah (interpelasi), dan juga hak untuk untuk melakukan penyelidikan (angket/enquete). Pasal 69 ayat (1) dan (2), serta Pasal 70 menyatakan UUDS menyatakan;

"Dewan Perwakilan Rakyat mempunyai hak interpelasi dan hak menaya; anggotaanggota mempunyai hak menanya". "Menteri-menteri memberikan kepada Dewan Perwakilan Rakyat, baik dengan lisan maupun dengan tertulis, segala penerangan yang dikehendaki menurut ayat yang lalu dan yang pemberiannya dianggap tidak berlawanan dengan kepentingan umum Republik Indonesia." "Dewan Perwakilan Rakyat mempunyai hak menyelidiki (enquete), menurut aturan-aturan yang ditetapkan dengan undang-undang". ${ }^{46}$

Dalam mahakarya disertasi Adnan Buyung Nasution, dijelaskan bahwa diundangkannya UUDS 1950 menandai babak baru sistem pemerintahan parlementer. Hal ini diakuinya oleh karena berdasar UUDS, pemerintah dapat dijatuhkan oleh parlemen. Konstitusi ini menetapkan struktur pemerintahan parlementer yang menempatkan Presiden memegang fungsi seremonial belaka. ${ }^{47}$ Artinya secara tekstual dapat dipahami bahwa lahirnya hak interpelasi, hak angket, dan menyatakan pendapat oleh DPR, tidak dapat dilepaskan dari menguatnya sistem parlementer di era tersebut.

Pengaturan demikian praksis menjadi tiada ketika Presiden Soekarno menetapkan Dekrit 5 Juli 1959, yang memberlakukan kembali UUD 1945. Harapan tersebut tidak lain untuk mengembalikan cita sistem presidensiel, meskipun politik hukum yang lahir pasca dekrit justru membawa sistem pemerintahan menjadi semi presidensiel atau kental dengan aroma parlementer. ${ }^{48}$

Ketika era reformasi politik dan konstitusi bergulir, wacana angket kembali menguat dalam tataran perdebatan politik hukum perubahan UUD. Buku ke III jilid 2 Naskah Komperhensif Perubahan UUD merekam beberapa pandangan para perumus

\footnotetext{
${ }^{46}$ Pasal 70 UUDS 1950

${ }^{47}$ Adnan Buyung Nasution, 1995, Aspirasi Pemerintahan Konstitusional di Indonesia, Jakarta: Pustaka Utama Grafiti, hlm. 28.

${ }^{48}$ Titik pijak pandangan penulis, didasari dengan kedudukan MPR sebagai lembaga tertinggi negara. Ada begitu banyak referensi ilmiah yang dapat dirujuk terkait hal ini. Sebut saja salah satunya AB Kusuma, Sistem Pemerintahan Pendiri Negara vs Sistem Pemerintahan era Reformasi, Jakarta: UI Press, 2011.
} 
perubahan UUD (the second framer of constitution) perihal pentingnya pengaturan hak angket dalam konstitusi.

Jika dianalisis secara mendalam, pendekatan historis ini berhasil mengidentifikasi beberapa hal. Pertama, secara historis tidak ada satupun klausul baik eksplisit maupun implisit, yang menyatakan bahwa hak angket dapat dialamatkan kepada organ-organ negara independen. Perdebatan politik hukum yang muncul hanya melahirkan subjek tunggal yaitu pemerintah yang bermuara pada Presiden sebagai pucuk tertinggi kekuasaan eksekutif. ${ }^{49}$ Kedua, lahirnya hak interpelasi, angket dan hak menyatakan pendapat, merupakan instrumen perimbangan kekuasaan terhadap pemerintah. Konstruksi checks and balances semata-mata dibangun atas hubungan legislatif terhadap eksekutif. Artinya DPR memainkan perannya sebagai cabang kekuasaan yang memiliki fungsi pengawasan terhadap jalannya pemerintahan (eksekutif). Patut diingat, secara historis tidak ada satupun perdebatan politik hukum yang muncul dan menegaskan bahwa angket dapat dialamatkan kepada cabang kekuasaan yudisial dan atau organ-organ negara independen (KY-KPU-KPK).

Ketiga lazim dipahami, jika proses hulu angket merupakan kontrol DPR terhadap eksekutif, maka hilirnya merupakan mosi tidak percaya DPR. Pada prinsipnya hakhak DPR (interpelasi, angket, hak menyatakan pendapat) yang dijamin UUD merupakan pintu masuk DPR dalam menggulingkan rezim pemerintahan. Artinya

${ }^{49}$ Lukman Hakim Saifuddin yang menekankan secara eksplisit bahwa kewenangan DPR patut diikuti dengan beberapa hak yang patut dimiliki. Salah satunya ialah hak angket yang merupakan hak untuk melakukan penyelidikan terhadap suatu permasalahan Lukman Hakim memberikan garis penekanan bahwa fungsi ini ditujukan pada konteks pemerintah selaku pemangku kekuasaan eksekutif. Frans F. H. Matrutty juga menyampaikan bahwa hak angket merupakan instrumen pengawasan DPR terhadap pemerintah (eksekutif). Valina Singka Subekti dari Fraksi Utusan Golongan yang menyatakan hak angket dan interpelasi seyogyanya di atur dalam batang tubuh UUD. Kemudian Fraksi PDI-P yang diwakili oleh Pataniari Siahaan menyatakan secara eksplisit bahwa hak angket merupakan instrumen pengawasan DPR.Artinya DPR mengawasi jalannya pemerintahan, dengan demikian anggota DPR mempunyai hak meminta keterangan hak interpelasi, hak melakukan penyelidikan atau hak angket, hak tanya terhadap sesuatu masalah kepada Presiden. Ali Hardi Kyaidemak menyampaikan 14 butir usulan dari Fraksi PPP yang salah satu poinnya membahas tentang hak angket DPR. Khususnya pada poin ke 10, PPP mengusulkan agar DPR mempunyai instrumen pengawasan terhadap jalannya pemerintahan. Sebagaimana diusulkan bahwa DPR mempunyai hak interpelasi, hak menyatakan pendapat, hak mengajukan/persetujuan terhadap seseorang, hak penyelidikan (angket) dan hak-hak lain yang selanjutnya diatur dalam undang-undang.

Slamet Efendy Yusuf dari Fraksi Golkar, dengan tegas menyatakan bahwa hilir dari hak interpelasi, angket, dan menyatakan pendapat ialah mosi ketidakpercayaan terhadap pemerintah. Efendy Yusuf berbeda pendapat dengan beberapa ahli yang telah menyatakan bahwa pengaturan hak angket tidak begitu relevan dengan sistem presidensil. Efendy Yusuf dengan tegas beranggapan bahwa tidak ada relevansi antara presidensil dengan parlementer terhadap hak angket DPR. Semua itu wajib diatur pada level konstitusi Lihat, Mahkamah Konstitusi RI, 2010, Naskah Komprehensif Perubahan UUD Negara RI Indonesia Tahun 1945; Latar Belakang, Proses, dan Hasil Pembahasan 1999-2002, BUKU KE III, Jilid 2, Jakarta: Sekretariat Jenderal MKRI, hlm. 706, 709, 925, 927, 934, dan 978. 
instrument hak angket DPR merupakan pintu masuk (entrypoint) dalam melakukan proses impeachment terhadap Presiden dan atau Wakil Presiden. Oleh karena itulah ketika angket dialamatkan kepada organ-organ negara independen, hal tersebut menjadi sangat tidak relevan.

Selanjutnya, masuk pada pendekatan konseptual. Pada titik ini, secara konsep penggunaan hak angket kepada organ-organ negara independen akan menabrak beberapa tatanan konseptual di bidang hukum dan politik ketatanegaraan. Pertama, dilihat dari posisi teoritik komisi-komisi negara independen, maka KNI (KY-KPUKPK) tidak masuk dalam wilayah eksekutif, legislatif, maupun yudikatif. Klaster yang paling tepat dalam struktur ketatanegaraan ialah cabang kekuasaan mandiri/independen, seperti pada bab-bab sebelumnya sudah dijelaskan penulis melalui beberapa doktrin yang ada. Bahwa KNI merupakan cabang kekuasaan keempat yang tipologi kewenangannya melaksanakan fungsi campur sari. Bisa quasi eksekutif, quasi legislatif ataupun quasi yudisial atau bersifat mix function dari beberapa tipologi tersebut.

Kedua, jika dilihat dari pembatasan kekuasaan dan hubungan kewenangannya, maka hak angket menjadi tidak relevan dialamatkan kepada komisi negara independen. Lantas apakah KNI menjadi poros cabang kekuasaan yang anti dengan paham konstitusionalisme? Jawabannya tentu tidak. Sebagaimana telah disusun oleh penulis, masing-masing komisi negara independen (KY, KPU, dan KPK) yang dijadikan objek studi penulis, tidak ada satupun kewenangan bahkan hubungan administratif kelembagaan yang berdiri bebas tanpa perimbangan cabang kekuasaan lain. Mulai dari pengangkatan komisioner, kewenangan, sampai dengan tanggung jawab administratif kelembagaan, semua beririsan langsung dengan cabang kekuasaan eksekutif, legislatif, maupun yudikatif.

Ketiga, terdapat persoalan serius jika angket dapat ditujukan kepada komisikomisi negara independen. Sebab patut diingat terdapat komisi negara independen yang menjadi badan-badan lain atau komponen yang berhubungan dengan penyelenggaraan kekuasaan kehakiman. Seperti misalnya KPK. Denny Indrayana menyatakan terdapat beberapa Putusan MK yang mengafirmasi bahwa KPK merupakan bagian dari proses penyelenggaraan kekuasaan kehakiman. ${ }^{50}$ Jika DPR

\footnotetext{
${ }^{50}$ Pengelompokan beberapa Putusan MK yang disusun oleh Indrayana, semakin menguatkan bahwa KPK tidak dapat dijadikan objek hak angket. Mengingat KPK me"Pertimbangan Putusan MK Nomor 012-016-019/PUU-IV/2006, hlm. 269, MK mengatakan "KPK dapat dianggap penting secara konstitusional (constitutionally important) dan termasuk lembaga yang fungsinya berkaitan dengan kekuasaan kehakiman sebagaimana dimaksud oleh Pasal 24 Ayat (3) UUD 1945";"Pertimbangan Putusan MK Nomor 5/PUU/IX/2011 halaman 75-76, MK menegaskan, "KPK adalah lembaga negara independen yang diberi tugas dan wewenang khusus antara lain melaksanakan sebagian fungsi yang terkait dengan kekuasaan kehakiman untuk melakukan penyelidikan, penyidikan, dan penuntutan ..."; ..."dan Pertimbangan Putusan MK Nomor 49/PUU-XI/2013 halaman 30, MK kembali menegaskan, "Pembentukan lembaga yang terkait dengan fungsi kekuasaan kehakiman termasuk KPK mempunyai
} 
tetap bersikukuh dengan hak angket, maka manuver politiknya yang mengatasnamakan hak angket dapat dikategorikan sebagai perbuatan menghalanghalangi proses peradilan (obstruction of justice). ${ }^{51}$

Keempat, perlu dipahami. Tanpa menggunakan hak angket, akuntabilitas kelembagaan komisi negara independen (KY-KPU-KPK) telah dilakukan dengan proses laporan tahunan kinerja di hadapan DPR. Artinya secara administratif kelembagaan, kinerja dan penggunaan anggaran komisi negara independen dipertanggungjawabkan dihadapan DPR dengan mekanisme rapat koordinasi atau rapat dengar pendapat. Konsekuensi logisnya hak angket kembali menjadi sangat tidak relevan dan cenderung menguras energi yang cukup besar.

Lebih lanjut, masuk dalam pendekatan yuridis normatif.Pertama, jika merujuk pada frasa tekstual UU MD3, terdapat beberapa hal yang mengatur perihal kewenangan hak angket DPR. Di antaranya Pasal 79 ayat (3), dan Pasal 208 ayat (1) dan (4) Undang-Undang Nomor 17 Tahun 2014 Tentang MD3. ${ }^{52}$ Dari masing-masing pengaturan di atas, Yuliandri memberikan penafsiran secara tekstual perihal Pasal 79 ayat (3) UU MD3. Yuliandri menyatakan bahwa pembelahan frasa-frasa dalam ketentuan Undang-Undang MD3 tersebut dapat dilakukan dengan pendekatan alternatif-kumulatif. Dengan demikian konteks alternatif kumulatif dalam ketentuan Pasal 79 ayat (3) Undang-Undang MD3 dapat berarti tiga hal: (1) Pelaksanaan suatu undang-undang saja. (2) Pelaksanaan suatu kebijakan saja. (3) Kemudian yang ketiga adalah pelaksanaan undang-undang dan kebijakan sekaligus. ${ }^{53}$

landasan konstitusional pada Pasal 24 ayat (3) UUD 1945".mpunyai kewajiban untuk memastikan, bahwa proses penyelenggaraan kekuasaan kehakiman benar-benar mandiri tanpa intervensi dari cabang kekusaan lain. Sebagaimana ditegaskan dalam Pasal 24 UUD 1945. Lihat Denny Indrayana, Keterangan Ahli Perkara Nomor 47/PUU-XV/2017.

${ }^{51}$ Lihat Eddy O.S Hiariej, “Obstruction of Justice dan Hak Angket KPK” Opini Kompas, 21 Juli 2017, hlm 7 .

52 Pasal 79 ayat (3) menyatakan:..."Hak angket sebagaimana dimaksud pada ayat (1) huruf b adalah hak DPR untuk melakukan penyelidikan terhadap pelaksanaan suatu undang-undang dan/atau kebijakan Pemerintah yang berkaitan dengan hal penting, strategis, dan berdampak luas pada kehidupan bermasyarakat, berbangsa, dan bernegara yang diduga bertentangan dengan peraturan perundangundangan" Pasal 208 ayat (1) dan (4) menyatakan; ...."Apabila rapat paripurna DPR sebagaimana dimaksud dalam Pasal 206 ayat (2) memutuskan bahwa pelaksanaan suatu undang-undang dan/atau kebijakan Pemerintah yang berkaitan dengan hal penting, strategis, dan berdampak luas pada kehidupan bermasyarakat, berbangsa, dan bernegara bertentangan dengan ketentuan peraturan perundangundangan, DPR dapat menggunakan hak menyatakan pendapat." ...."Keputusan sebagaimana dimaksud pada ayat (3) disampaikan oleh pimpinan DPR kepada Presiden paling lama 7 (tujuh) hari sejak keputusan diambil dalam rapat paripurna DPR"

53 Yuliandri, dalam risalah sidang perkara Nomor 36,37, 40,47, PUU-XV/2017, Perihal Pengujian Undang-Undang Nomor 17 Tahun 2014 Tentang MPR,DPR,DPD, dan DPRD, Sebagaimana telah diubah dengan Undang-Undang Nomor 42 Tahun 2014 Tentang MPR,DPR,DPD,dan DPRD, Terhadap UUDN RI Tahun 1945, “acara mendengarkan keterangan ahli pemohon", Rabu 13 September 2017, Jakarta: Sekretariat Jenderal MKRI, hlm 7. 
Tiga hal demikian merupakan tiga hal yang bersifat alternatif kumulatif. Namun patut diingat bahwa, hal tersebut baru sebatas mengenai objek bukan mengenai. Dalam konteks itu, penafsiran ruang lingkup objek tentu tidak dapat digeneralisir menjadi ruang lingkup subjek karena lingkup subjek dan objek hak angket dalam pasal tersebut ditentukan secara spesifik, dimana objeknya ada tiga alternatif, sedangkan subjeknya hanya satu, yaitu Pemerintah. ${ }^{54}$

Penulis berada pada posisi setuju dengan keterangan yang disampaikan oleh Yuliandri. Sebab, patut diingat bahwa, Pasal 208 ayat (1) dan (4) jelas memberikan penegasan eksplisit terhadap subjek. Hal ini dibuktikan bahwa hasil angket yang telah diparipurnakan dapat ditindak lanjuti dengan hak menyatakan pendapat kepada Presiden. Artinya subjek yang diatur dalam Pasal 79 ayat (3) UU MD3 hanya berlaku secara limitatif, yaitu pemerintah yang dalam hal ini ditujukan kepada Presiden.

Kedua, sangat berbahaya jika DPR menggunakan basis argumentasi yang tidak tepat, dengan memaknai pembelahan frasa itu ditunjukkan kepada semua pelaksana undang-undang. Pada akhirnya DPR akanberkesimpulan bahwa semua lembaga negara dapat dikenakan hak angket.Tentunya logika yang dibangun DPR menjadi irasional sebab, tidak ada satupun organ negara yang lepas dari tugas melaksanakan undang-undang. Pada titik tersebut, kewenangan DPR dalam menggunakan haknya menjadi senyawa absolut dan rawan akan penyalahgunaan kekuasaaan.

Melalui angket, DPR dapat berubah menjadi instrumen tirani baru yang mengancam seluruh sendi-sendi cabang kekuasaan dan lembaga negara, termasuk MK, MA, BPK, dan seluruh komisi-komisi negara independen lainnya. Oleh karena itu, sekiranya perlu diluruskan kembali subjek yang dapat dimintakan hak angket oleh DPR. Mengembalikan titahnya sebagai instrumen kontrol terhadap eksekutif merupakan pilihan politik hukum yang tepat demi menjaga konstelasi hubungan antar cabang kekuasaan dan lembaga negara.

\section{KESIMPULAN}

Hasil penelitian menunjukan bahwa, pertama, dari masing-masing komisi negara independen yang dijadikan objek studi pada riset ini (KY-KPU-KPK), tidak ada satupun komisi negara independen yang menegasikan paham konstitusionalisme. Meskipun riset-riset terdahulu telah membenarkan bahwa gejala kelahiran komisi negara independen di Indonesia tidak mempunyai cetak biru yang memadai, tetapi relatif mampu membangun hubungan kekuasaan berdasarkan prinsip checks and balances. Masing-masing komisi negara independen yang diteliti, beririsan langsung dengan cabang kekuasaan atau lembaga negara lainnya. Mulai dari mekanisme pengangkatan komisioner, hubungan kewenangan, sampai dengan hubungan

\footnotetext{
${ }^{54}$ Ibid, hlm 8 .
} 
akuntabilitas administratif kelembagaan. Kedua, hasil penelitian menunjukan, tidak terdapat relevansi antara hak angket dengan komisi negara independen (KY-KPUKPK). Hal ini dibuktikan dengan tiga pendekatan yang digunakan penulis, yakni historis, konseptual, dan yuridis normatif. Masing-masing alat ukur tersebut menunjukan hal yang sama. Bahwa hak angket hanya relevan jika dialamatkan kepada pemerintah (eksekutif) bukan terhadap komisi negara independen.

\section{DAFTAR PUSTAKA}

\section{Buku}

Adnan Buyung Nasution, 1995, Aspirasi Pemerintahan Konstitusional di Indonesia:

Studi Sosio Legal atas Konstituante 1956-1959, Jakarta: Pustaka Utama Grafiti.

Campbell Black, Henry1991, Black Dictionary, St.Paul, Minnesota: West Publishing. Denny Indrayana, 2016, Jangan Bunuh KPK; Kajian Hukum Tata Negara Penguatan

Komisi Pemberantasan Korupsi, Malang: Intrans Publishing.

Djayadi Hanan, 2014, Menakar Presidensialisme Multipartai di Indonesia; Upaya Mencari Format Demokrasi yang Stabil dan Dinamis Dalam Konteks Indonesia, MBandung: Mizan.

Munir Fuady, 2009, Teori Negara Hukum Modern, PT. Refika Aditama, Bandung F. Sugeng Istanto, 2007, Penelitian Hukum, Yogyakarta: Ganda.

Gunawan A. Tauda, 2012, Komisi Negara Independen; Eksistensi Independent Agencies Sebagai Cabang Kekuasaan Baru Dalam Sistem Ketatanegaraan, Yogyakarta: Genta Press.

Henk Schulte Nordholt dan Gery van Klinken, 2014, Politik Lokal di Indonesia, Jakarta: KITLV-Jakarta \& Yayasan Pustaka Obor Indonesia.

Jimly Asshidiqie, 2015, Penguatan Sistem Pemerintahan dan Peradilan, Jakarta: Sinar Grafika.

Jimly Asshiddiqie, 2010, Perkembangan dan Konsolidasi Lembaga Negara Pasca Reformasi, Jakarta: Sinar Grafika.

MKRI, risalah sidang perkara Nomor 36,37, 40,47, PUU-XV/2017, Perihal Pengujian Undang-Undang Nomor 17 Tahun 2014 Tentang MPR,DPR,DPD, dan DPRD, Sebagaimana telah diubah dengan Undang-Undang Nomor 42 Tahun 2014 Tentang MPR,DPR,DPD, dan DPRD, Terhadap UUDN RI Tahun 1945, “acara mendengarkan keterangan ahli pemohon”, Rabu 13 September 2017, Jakarta: Sekretariat Jenderal MKRI.

Mahkamah Konstitusi RI, 2010, Naskah Komprehensif Perubahan UUD Negara RI Indonesia Tahun 1945; Latar Belakang, Proses, dan Hasil Pembahasan 19992002, BUKU KE III, Jilid 2, Jakarta: Sekretariat Jenderal MKRI. 
Dialogia luridica: Jurnal Hukum Bisnis dan Investasi

Volume 10 Nomor 1, November 2018

Ni'matul Huda, 2016, Sengketa Kewenangan Lembaga Negara Dalam Teori dan Praktik di Mahkamah Konstitusi, Yogyakarta: UII Press.

Ni'matul Huda dan M. Imam Nasef, 2017, Penataan Demokrasi \& Pemilu di Indonesia Pasca Reformasi, Jakarta: Kencana.

Peter Mahmud Marzuki, 2005, Penelitian Hukum, Kencana Prenada, Jakarta: Media Group.

Samuel P.Huntington, 1991, The Third Wave : Democratization in the Late Twentieth Century, Norman: University Oklahoma Press.

Suparman Marzuki, 2011, Tragedi Politik Hukum HAM, Yogyakarta: Pustaka PelajarPusham UII.

Soerjono Soekanto, 1986, Pengantar Penelitian Hukum, Jakarta: UI Press.

Zainal Arifin Mochtar, 2016, Lembaga Negara Independen ; Dinamika, Perkembangan, dan Urgensi Penataannya Kembali Pasca Amandemen Konstitusi, Jakarta: Rajawali Press.

\section{Jurnal}

Bruce Ackerman, "The New Separation of Power", The Harvard Law Review, Volume 113,HVLR 633, Januari 2000.

Dudu Duswara Machmudin, "Optimalisasi Peran Hakim Agung Dalam Penyelesaian Perkara Kasasi dan Peninjauan Kembali”, Jurnal Konstitusi Volume 12 Nomor 2, Juni 2015.

Mauro Cappeleti, "Who watches the watchmen?"A comparative Study on Judicial Responsibility, The American Journal of Comparative Law, Volume 31, No. $1,1983$.

Said Amir Arjomand, "Law, Political Reconstruction and Constitutional Politics”, Journal International Sociology, Volume 18 issue 1, Maret, 2003.

Susan D. Baer, "The Public Trust Doctrine - A Tool to Make Federal Administrative Agencies Increase Protection of Public Law and Its Resources", Boston, Boston College Environmental Affairs Law Review vol. 15, 1988.

\section{Penelitian, Makalah \& Artikel:}

Denny Indrayana, Keterangan Ahli Perkara Nomor 47/PUU-XV/2017

Eddy O.S Hiariej, "Obstruction of Justice dan Hak Angket KPK”, Opini Kompas, 21 Juli 2017

Emilio J Cardenas dan Hector M. Chaver, "Corruption, Accountability and Discipline of Judges in Latin America”, dalam Global Corruption Report, 2007,Corruption in judicial system, Transparency Internasional; Cambridge New York: University Press. 
Dialogia luridica: Jurnal Hukum Bisnis dan Investasi

Volume 10 Nomor 1, November 2018

\section{Peraturan Perundang-Undangan:}

Konstitusi Republik Indonesia Serikat Tahun 1949

Undang-Undang Dasar Sementara Tahun 1950

UUDN RI Tahun 1945 Setelah Perubahan

Undang-Undang Nomor 8 Tahun 1981 Tentang Hukum Acara Pidana, Lembaran Negara Republik Indonesia Tahun 1981.

Undang-Undang Nomor 30 Tahun 2002 Tentang Komisi Pemberantasan Tindak Pidana Korupsi, Lembaran Negara Republik Indonesia Tahun 2002 Nomor 137, Tambahan Lembaran Negara RI Nomor, 4250.

Undang-Undang Nomor 51 Tahun 2009 Tentang Peradilan TUN, Lembaran Negara Republik Indonesia Tahun 2009, Tambahan Lembaran Negara RI Nomor 5079.

Undang-Undang Nomor 15 Tahun 2011 Tentang Penyelenggara Pemilihan Umum, Lembaran Negara RI Tahun 2011, Nomor 101, Tambahan Lembaran Negara Republik Indonesis Nomor 5246.

Undang-Undang Nomor 18 Tahun 2011 Tentang Perubahan Atas Undang-Undang Nomor 22 Tahun 2004 Tentang Komisi Yudisial, Lembaran Negara Republik Indonesia Tahun 2011 Nomor 106, Tambahan Lembaran Negara RI Nomor, 5250 .

Undang-Undang Nomor 17 Tahun 2014 Tentang Majelis Permusyawaratan Rakyat, Dewan Perwakilan Rakyat, Dewan Perwakilan Daerah, Dewan Perwakilan Rakyat Daerah, Lembaran Negara Republik Indonesia Tahun 2014 Nomor 182, Tambahan Lembaran Negara RI Nomor, 5568.

\section{Produk Hukum Lembaga Peradilan :}

Putusan MK Nomor 005/PUU-IV/2006

Putusan Nomor 012-016-019/PUU-IV/2006

Putusan MK Nomor 5/PUU/IX/2011

Putusan MK Nomor 49/PUU-XI/2013

Putusan MK Nomor 21/PUU-XII/2014

Surat Edaran Mahkamah Agung (SEMA) Nomor 7 Tahun 2010 Tentang Petunjuk Teknis Sengketa Mengenai Pemilihan Umum Kepala Daerah. 